\title{
High performance tandem perovskite-silicon solar cells with very large bandgap photoelectrodes
}

\author{
A. B. Nikolskaia ${ }^{1}$, M. F. Vildanova ${ }^{1}$, S. S. Kozlov ${ }^{1}$, O. V. Almjasheva ${ }^{2}$, \\ V. V. Gusarov ${ }^{2,3}$, O. I. Shevaleevskiy ${ }^{1}$ \\ ${ }^{1}$ Department of Solar Photovoltaics, Institute of Biochemical Physics RAS, \\ Kosygin St. 4, Moscow, 119334, Russia \\ ${ }^{2}$ Saint Petersburg Electrotechnical University "LETI", \\ Saint-Petersburg, Professora Popova St., 5, Saint Petersburg, 197376, Russia \\ ${ }^{3}$ Ioffe Physical-Technical Institute RAS, \\ Politekhnicheskaya St., 26, Saint Petersburg, 194021, Russia \\ shevale2006@yahoo.com, victor.v.gusarov@gmail.com
}

PACS 84.60.Jt

DOI 10.17586/2220-8054-2021-12-2-246-251

\begin{abstract}
Nanostructured layers of metal oxides with very large bandgaps $\left(E_{g}>5 \mathrm{eV}\right)$, such as $\mathrm{ZrO}_{2}$ and $\mathrm{HfO}_{2}$, were used as photoelectrodes in semitransparent perovskite solar cells (PSCs) with the device architecture of glass/FTO/c- $\mathrm{TiO}_{2} / \mathrm{ZrO}_{2}\left(\right.$ or HfO $\left._{2}\right) / \mathrm{CH}_{3} \mathrm{NH}_{3} \mathrm{PbI}_{3} / \mathrm{PTAA} / \mathrm{PEDOT}: \mathrm{PSS} / \mathrm{FTO} / \mathrm{glass}$ The obtained PSCs were used as top elements for manufacturing high-performance four-terminal tandem perovskite-silicon solar cells. The comparative analysis of photovoltaic parameters measured for PSCs, crystalline silicon (c-Si) solar cells and tandem PSC/c-Si solar cells demonstrated that the application of very large-bandgap materials allows to improve the PSC performance and to increase the efficiency of tandem PSC/c-Si solar cell up to $\sim 24 \%$ in comparison with a standalone c-Si solar cell.
\end{abstract}

Keywords: photoelectrode, perovskite, solar cells, tandem solar cells, solar photovoltaics.

Received: 3 January 2021

Revised: 1 April 2020

\section{Introduction}

To date, well-developed crystalline silicon (c-Si) solar cells under AM1.5G $\left(1000 \mathrm{~W} / \mathrm{m}^{2}\right)$ lighting conditions demonstrate nearly $25 \%$ power conversion efficiency (PCE), that is already approaching their practical limit [1,2]. The further increase of c-Si cell performance can be attained by integration into the tandem configuration. Extensive possibilities for the design of tandem cells are associated with the recent appearance of effective perovskite solar cells (PSCs) $[3,4]$. This type of solar cell, in which a perovskite layer based on organic-inorganic hybrid compounds with a common $\mathrm{ABX}_{3}\left(\mathrm{~A}-\mathrm{CH}_{3} \mathrm{NH}_{3}^{+}, \mathrm{HC}\left(\mathrm{NH}_{2}\right)_{2}^{+}, \mathrm{B}-\mathrm{Pb}^{2+}, \mathrm{Sn}^{2+}, \mathrm{X}-\mathrm{I}^{-}, \mathrm{Br}^{-}, \mathrm{Cl}^{-}\right)$formula is deposited on the surface of a nanostructured photoelectrode (usually $\mathrm{TiO}_{2}$ ), has attracted a considerable interest as the most demanded and cost-effective photovoltaic (PV) devices for the future mass production [5-7].

In tandem, perovskite-silicon (PSC/c-Si) solar cells PSCs are usually used as top elements in combination with bottom c-Si cells [8,9]. Tandem PSC/c-Si solar cells are commonly fabricated in two configurations: two-terminal and four-terminal $[10,11]$. The overall current output of the two-terminal tandem cell is limited by the lower of the currents generated by the connected in series individual sub cells That is why a four-terminal tandem configuration, in which the top and bottom cells are mechanically stacked and electrically isolated from each other, is preferable [12, 13].

The efficiency and the degree of transparency of top cell strongly affects the tandem PSC/c-Si solar cell performance and depend on the structure and transport characteristics of the photoelectrodes used in PSCs [14-16]. In our previous works [17,18], we demonstrated that very wide-bandgap nanostructured materials, like $\mathrm{ZrO}_{2}$ with $E_{g}$ values of 5.26 and $5.53 \mathrm{eV}$ for two direct band transitions and $\mathrm{HfO}_{2}$ with the $E_{g}$ value of $5.56 \mathrm{eV}$ for indirect band transition, can be successfully used as photoelectrodes for PSCs. The incorporation of mesoscopic $\mathrm{ZrO}_{2}$ (or $\mathrm{HfO}_{2}$ ) layer into the PSCs with the standard architecture of glass/FTO/c- $\mathrm{TiO}_{2} / \mathrm{ZrO}_{2}$ (or $\left.\mathrm{HfO}_{2}\right) / \mathrm{CH}_{3} \mathrm{NH}_{3} \mathrm{PbI}_{3} / \mathrm{Spiro}-\mathrm{MeO}-\mathrm{TAD} / \mathrm{Au}$ led to the improvement of PV performance of PSCs [17]. However, these PV devices cannot be used as top elements in tandem systems because of the low optical transparency of Spiro-MeO-TAD layer and Au contacts in the visible range of the visible light spectrum. PTAA or P3HT as a hole transporting material and PEDOT:PSS-based counter electrode can be used for fabrication semi-transparent PSCs [19,20].

In this work, photoelecrodes based on very wide-bandgap materials such as $\mathrm{ZrO}_{2}$ and $\mathrm{HfO}_{2}\left(E_{g}>5 \mathrm{eV}\right)$ were successfully used for fabrication of semi-transparent PSCs with the cell architecture of glass/FTO/c- TiO $/ 2 / \mathrm{ZrO}_{2}($ or $\left.\mathrm{HfO}_{2}\right) / \mathrm{CH}_{3} \mathrm{NH}_{3} \mathrm{PbI}_{3} / \mathrm{PTAA} / \mathrm{PEDOT}$ :PSS/FTO/glass under ambient conditions. The obtained PSCs were used as top 
elements for manufacturing highly efficient four-terminal tandem PSC/c-Si solar cells. The PV performance of PSCs, standalone c-Si and tandem PSC/Si solar cells was studied. The obtained results provide a novel effective approach to increase the overall efficiency of light conversion to electricity.

\section{Experimental}

\subsection{Materials and samples preparation}

$\mathrm{ZrO}_{2}$ and $\mathrm{HfO}_{2}$ nanoparticles were obtained by hydrothermal treatment of co-precipitated zirconium and hafnium hydroxides from solutions of the corresponding metal salts [21]. $\mathrm{TiO}_{2}$ nanoparticles (P25 Aeroxide Degussa) were purchased from Sigma-Aldrich (USA) and were used for fabrication of state-of-the-art $\mathrm{TiO}_{2}$ photoelectrode [22]. Thick pastes from $\mathrm{MO}_{2}$ (where $\mathrm{M}=\mathrm{Ti}, \mathrm{Zr}$ or Hf) nanopowders were prepared in organic solvent following the method described in [23]. The pastes were dissolved in ethanol in mass ratio 1:5 and spin-coated onto FTO conductive glass (Solaronix, $2 \times 2 \mathrm{~cm}$ ) covered by compact layer $\left(\mathrm{c}-\mathrm{TiO}_{2}\right)$ with subsequent annealing at $500^{\circ} \mathrm{C}$ for $30 \mathrm{~min}$. Mesoscopic $\mathrm{MO}_{2}$ photoelectrodes with thickness $180-220 \mathrm{~nm}$ were obtained.

Perovskite $\left(\mathrm{CH}_{3} \mathrm{NH}_{3} \mathrm{PbI}_{3}\right)$ layers were formed on $\mathrm{MO}_{2}$ using a conventional one-step deposition method [24, 25]. PTAA with Li-TFSI and 4-tert-Butylpyridine additives in toluene was used as a hole transporting material. It was drop-casted onto the perovskite surface and then covered by counter electrode of PEDOT:PSS/FTO according to the procedure described elsewhere [19]. PTAA, PEDOT:PSS, Li-TFSI and 4-tert-Butylpyridine were purchased from Sigma Aldrich. All the steps of PSC fabrication process were provided under ambient conditions with a relative humidity about $40 \%$.

Samples of c-Si solar cells were kindly provided by the research group of G. Untila from Skobeltsyn Institute of Nuclear Physics, Moscow State University.

\subsection{Characterization studies}

The optoelectronic properties of $\mathrm{MO}_{2}$ photoelectrodes were characterized using UV-vis spectroscopy (Shimadzu UV-3600 spectrophotometer (Shimadzu, Japan) with an ISR-3100 integrating sphere at wavelengths ranging from 300-1200 nm). The measurements of the PV parameters for PSCs fabricated, for c-Si solar cells and for tandem PSC/c$\mathrm{Si}$ solar cells were provided under standard illumination conditions of $1000 \mathrm{~W} / \mathrm{m}^{2}$ (AM1.5G) using Semiconductor Characterization System (Keithley, USA). The incident photon-to-current conversion efficiency (IPCE) spectra were recorded using QEX10 Solar Cell Quantum Efficiency Measurement System (PV Measurements, USA) in the range of $300-1100 \mathrm{~nm}$.

\section{Results and discussion}

Optical transmittance spectra of mesoscopic $\mathrm{MO}_{2}$ photoelectrodes are plotted in Fig. 1. All samples are characterized by a high degree of transparency in the visible light range and can be used for constructing top elements in tandem systems. It is seen that transmittance region is wider for very wide-bandgap materials $\left(\mathrm{ZrO}_{2}\right.$ and $\left.\mathrm{HfO}_{2}\right)$ than for $\mathrm{TiO}_{2}$ due to the area of 250-350 nm in UV radiation range. This correlates with energy bandgap data obtained in earlier studies [18].

Semi-transparent PSCs with the architecture glass/FTO/c- $\mathrm{TiO}_{2} / \mathrm{MO}_{2} / \mathrm{CH}_{3} \mathrm{NH}_{3} \mathrm{PbI}_{3} / \mathrm{PTAA} / \mathrm{PEDOT}$ : PSS/FTO/glass were fabricated under ambient conditions. Comparative $J-V$ curves for all samples recorded under standard illumination $\left(1000 \mathrm{~W} / \mathrm{m}^{2}\right.$, AM1.5G) are shown in Fig. 2. The PV parameters of PSCs including short circuit current density $\left(J_{S C}\right)$, open circuit voltage $\left(V_{O C}\right)$, fill factor $(F F)$ and power conversion efficiency (PCE) are listed in Table 1.

TABLE 1. The PV characteristics of PSC devices based on mesoscopic $\mathrm{MO}_{2}$ photoelectrodes

\begin{tabular}{|c|c|c|c|c|}
\hline Photoelectrode type & $J_{S C}, \mathrm{~mA} / \mathrm{cm}^{2}$ & $V_{O C}, \mathrm{~V}$ & $F F$, a.u. & PCE, \% \\
\hline $\mathrm{TiO}_{2}$ & $17.58 \pm 0.17$ & $0.99 \pm 0.01$ & $0.69 \pm 0.01$ & $11.94 \pm 0.15$ \\
\hline $\mathrm{ZrO}_{2}$ & $16.30 \pm 0.24$ & $1.06 \pm 0.02$ & $0.74 \pm 0.02$ & $12.72 \pm 0.29$ \\
\hline $\mathrm{HfO}_{2}$ & $13.40 \pm 0.32$ & $1.06 \pm 0.01$ & $0.70 \pm 0.02$ & $9.96 \pm 0.36$ \\
\hline
\end{tabular}

PSC devices with mesoscopic $\mathrm{TiO}_{2}$ photoelectrodes show the average PCE of $11.94 \%$. The substitution of $\mathrm{TiO}_{2}$ layer by a very wide-bandgap materials leads to the improvement of the $V_{O C}$ values, which is attributed to the difference in the conduction band positions of $\mathrm{TiO}_{2}$ and $\mathrm{ZrO}_{2}\left(\mathrm{HfO}_{2}\right)$ [17, 18]. However, a drop in $J_{S C}$ values is found with incorporation of $\mathrm{ZrO}_{2}$ and $\mathrm{HfO}_{2}$ materials, which can be explained by their insulating nature [18]. 


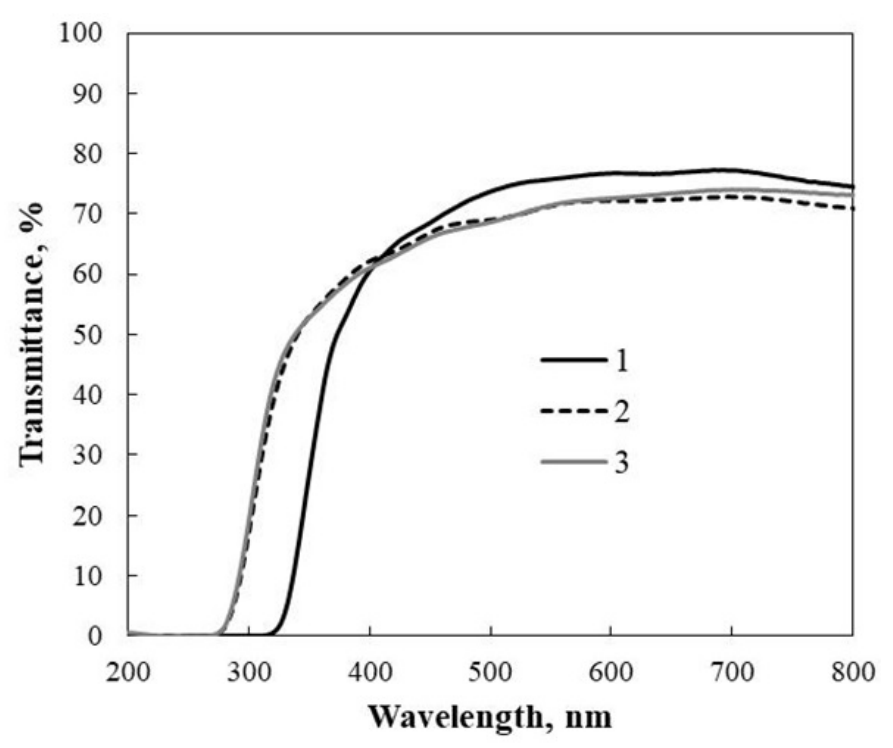

FIG. 1. Optical transmittance spectra of mesoscopic $\mathrm{MO}_{2}$ photoelectrodes $\left(1-\mathrm{TiO}_{2}, 2-\mathrm{ZrO}_{2}\right.$, $3-\mathrm{HfO}_{2}$ )

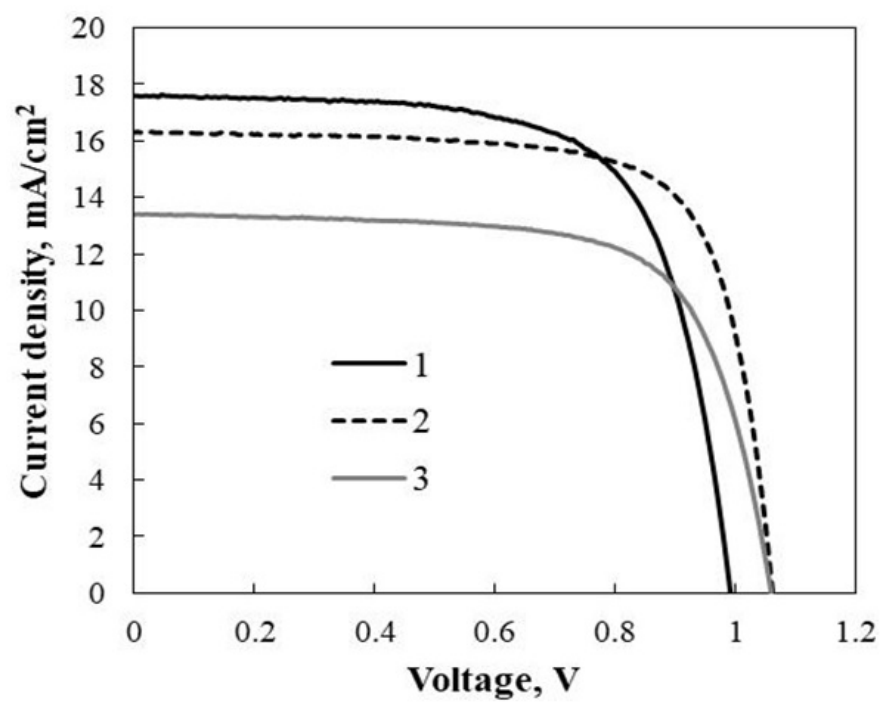

FIG. 2. $J-V$ curves for the PSC devices based on mesoscopic $\mathrm{MO}_{2}$ photoelectrodes $\left(1-\mathrm{TiO}_{2}\right.$, $\left.2-\mathrm{ZrO}_{2}, 3-\mathrm{HfO}_{2}\right)$

The highest average performance of $12.72 \%$ is demonstrated by PSC samples with $\mathrm{ZrO}_{2}$ photoelectrode and it is $6.5 \%$ higher than for $\mathrm{TiO}_{2}$-based device. The observed difference is due to various charge transfer mechanisms. The charge transfer in $\mathrm{TiO}_{2}$ layer is carried out through the conduction band, whereas the charge transfer in $\mathrm{ZrO}_{2}$ photoelectrode occurs via the hopping conduction mechanism through localized states within forbidden zone [17]. As a result, the recombination losses at the $\mathrm{ZrO}_{2}$ /perovskite interface are lower than for $\mathrm{TiO}_{2} /$ perovskite. The PCE of $\mathrm{HfO}_{2}$-based PSCs is lower than for others due to lower $J_{S C}$ values. This is more likely attributed to the insufficient layer morphology and less favorable positions of the electronic states in $\mathrm{HfO}_{2}$ forbidden zone [18].

All fabricated PSC devices based on mesoscopic $\mathrm{MO}_{2}$ photoelectrodes were used as top elements in four-terminal tandem PSC/c-Si solar cells. The c-Si solar cells were used as bottom elements and were mechanically stacked with PSCs according scheme on Fig. 3a. The $J-V$ curves measured under standard illumination $\left(1000 \mathrm{~W} / \mathrm{m}^{2}, \mathrm{AM} 1.5 \mathrm{G}\right)$ as well as the IPCE data for standalone c-Si sample and for c-Si elements in combination with PSCs are shown on Fig. $3 b$ and Fig. 3c. According to the IPCE spectra, tandem PSCs/c-Si systems provide efficient output in a wide range 
(from 300 to $1000 \mathrm{~nm}$ ) of solar spectrum. The performance of the bottom c-Si cells is shown to be nearly independent on the type of material used as photoelectrode in the top PSC (Fig. 3c).
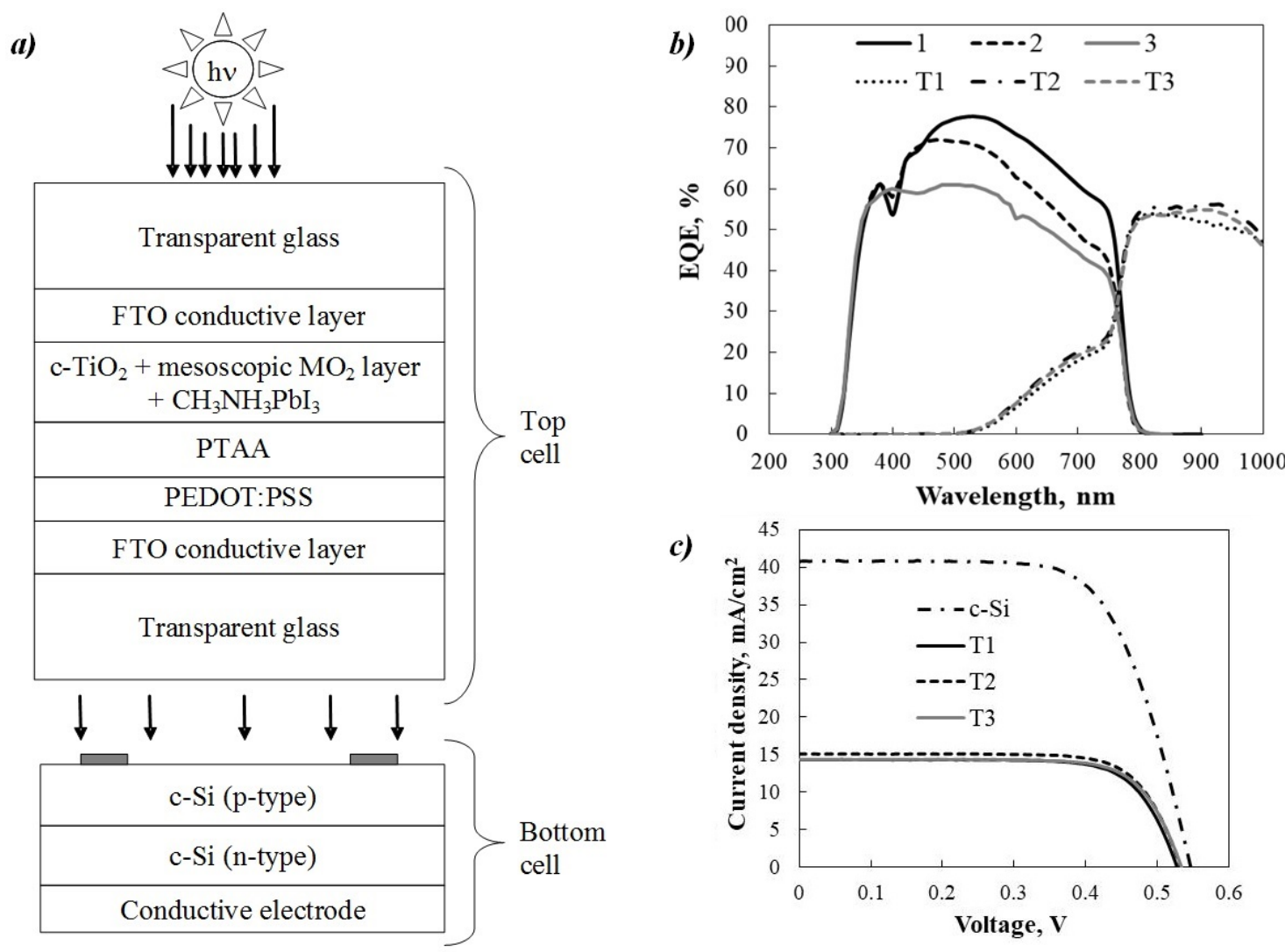

FIG. 3. Scheme of four-terminal tandem PSC/c-Si solar cell (a), the IPCE spectra (b) and the $J-V$ curves (c) for c-Si solar cell, PSCs with mesoscopic $\mathrm{MO}_{2}$ photoelectrodes $\left(1-\mathrm{TiO}_{2}, 2-\mathrm{ZrO}_{2}, 3-\right.$ $\mathrm{HfO}_{2}$ ) and for c-Si in combination with PSC (T1 - PSC with $\mathrm{TiO}_{2}, \mathrm{~T} 2-\mathrm{PSC}$ with $\mathrm{ZrO}_{2}$, T3 - PSC with $\mathrm{HfO}_{2}$ )

The PV parameters of the bottom c-Si cells and comparative charts, illustrating the relative contributions of both top and bottom sub-cells into the resulting PCE of tandem PSC/c-Si solar cells, are presented in Table 2 and Fig. 4. The overall conversion efficiency for all tandem systems is higher than for standalone c-Si and strongly depends on the top cell PCE. The best performance under standard illumination conditions (1000 W/m², AM1.5G) was achieved for PSC based on mesoscopic $\mathrm{ZrO}_{2}$ photoelecrode in combination with c-Si. It was found to be $18.69 \%$, which exceeded the PCE of a standalone c-Si solar cell by $\sim 24 \%$. The obtained data reveals that PSCs based on very wide-bandgap materials can be successfully used as top elements in tandem systems with the bottom c-Si cells and its allows to significantly increase the overall conversion efficiency. Also, mesoscopic $\mathrm{ZrO}_{2}$-based material can be an efficient alternative to standard $\mathrm{TiO}_{2}$ layer as photoelectrode for PSCs.

\section{Conclusions}

Photoelecrodes based on very wide-bandgap materials such as $\mathrm{ZrO}_{2}$ and $\mathrm{HfO}_{2}\left(\mathrm{E}_{g}>5 \mathrm{eV}\right)$ were successfully used for fabrication of high efficient semi-transparent PSCs with the cell architecture of glass/FTO/c- $\mathrm{TiO} \mathrm{O}_{2} / \mathrm{ZrO}_{2}($ or $\left.\mathrm{HfO}_{2}\right) / \mathrm{CH}_{3} \mathrm{NH}_{3} \mathrm{PbI}_{3} / \mathrm{PTAA} / \mathrm{PEDOT}: \mathrm{PSS} / \mathrm{FTO} /$ glass under ambient conditions at high humidity levels $(\sim 40 \%)$. The best PCE of $12.72 \%\left(1000 \mathrm{~W} / \mathrm{m}^{2}\right.$, AM1.5G) was demonstrated by PSC samples with $\mathrm{ZrO}_{2}$ photoelectrode and it was $6.5 \%$ higher than for state-of-the-art $\mathrm{TiO}_{2}$-based device.

Fabricated PSCs were used as top elements in four-terminal tandem PSC/c-Si solar cells. Comparative analysis of PV parameters for bottom c-Si elements in combination with PSC based on $\mathrm{TiO}_{2}, \mathrm{ZrO}_{2}$ or $\mathrm{HfO}_{2}$ photoelectrodes revealed that the PCE value of a top cell was a major factor affecting the overall tandem cell performance. The best PCE was achieved for the tandem PSC/c-Si solar cell with PSC based on $\mathrm{ZrO}_{2}$ photoelectrode. It was found to be $18.69 \%\left(1000 \mathrm{~W} / \mathrm{m}^{2}, \mathrm{AM} 1.5 \mathrm{G}\right)$ and it exceeded the PCE value for a standalone c-Si solar cell by $24 \%$. 
TABLE 2. The PV characteristics of c-Si solar cells in combination with PSC devices (T1 - PSC with $\mathrm{TiO}_{2}, \mathrm{~T} 2$ - $\mathrm{PSC}$ with $\mathrm{ZrO}_{2}$, T3 - $\mathrm{PSC}$ with $\mathrm{HfO}_{2}$ )

\begin{tabular}{|c|c|c|c|c|}
\hline Tandem type & $J_{S C}, \mathrm{~mA} / \mathrm{cm}^{2}$ & $V_{O C}, \mathrm{~V}$ & $F F$, a.u. & PCE, \% \\
\hline Standalone c-Si & $40.79 \pm 0.23$ & $0.55 \pm 0.02$ & $0.68 \pm 0.02$ & $15.07 \pm 0.11$ \\
\hline $\mathrm{T} 1$ & $14.32 \pm 0.14$ & $0.53 \pm 0.01$ & $0.74 \pm 0.01$ & $5.61 \pm 0.15$ \\
\hline $\mathrm{T} 2$ & $15.10 \pm 0.18$ & $0.54 \pm 0.02$ & $0.74 \pm 0.01$ & $5.97 \pm 0.22$ \\
\hline $\mathrm{T} 3$ & $14.36 \pm 0.19$ & $0.54 \pm 0.01$ & $0.74 \pm 0.02$ & $5.71 \pm 0.22$ \\
\hline
\end{tabular}

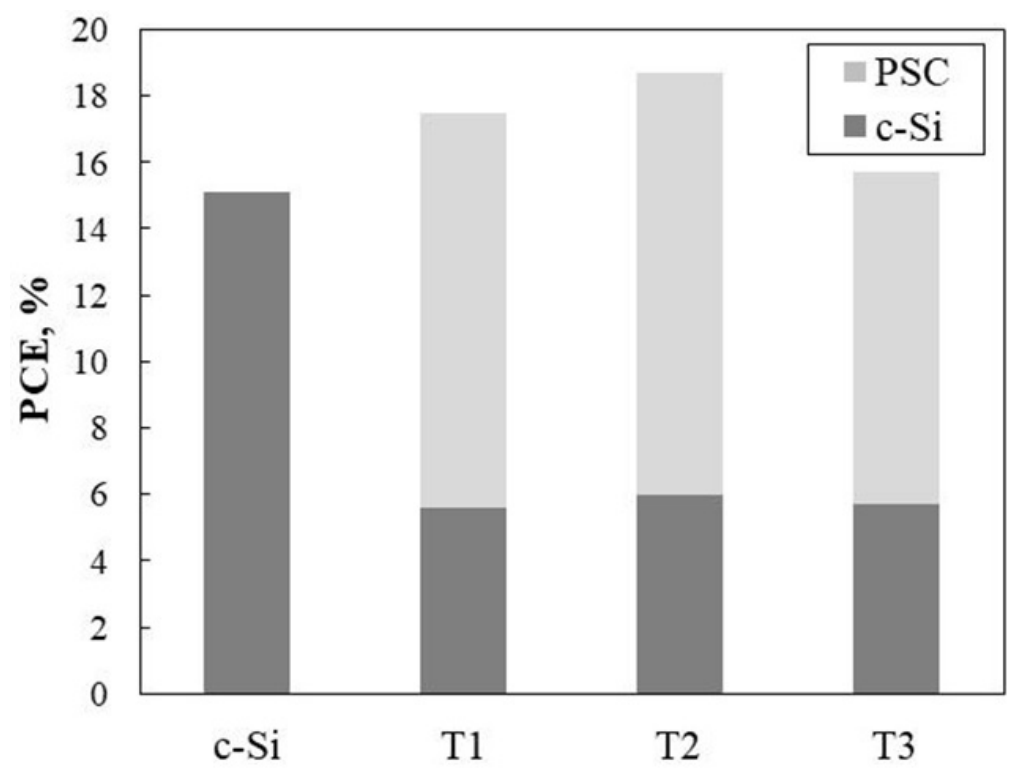

FIG. 4. Comparative diagrams for standalone c-Si solar cell and for four-terminal tandem PSC/c-Si solar cells ( $\mathrm{T} 1$ - PSC with $\mathrm{TiO}_{2}, \mathrm{~T} 2$ - $\mathrm{PSC}$ with $\mathrm{ZrO}_{2}, \mathrm{~T} 3$ - $\mathrm{PSC}$ with $\mathrm{HfO}_{2}$ )

The obtained results demonstrated that application of very wide-bandgap materials as photoelectrodes in PSCs allows not only to improve their performance under ambient conditions but also to increase significantly the overall conversion efficiency of four-terminal tandem PSC/c-Si solar cells.

\section{Acknowledgements}

This work is supported by the Russian Foundation for Basic Research according to the research project No19-0801042.

\section{References}

[1] Green M.A., Dunlop E.D., Hohl-Ebinger J., Yoshita M., Kopidakis N., Hao X. Solar cell efficiency tables (version 56). Prog. Photovolt.: Res. Appl., 2020, 28, NREL/JA-5900-77544.

[2] Battaglia C., Cuevas A., De Wolf S. High-efficiency crystalline silicon solar cells: status and perspectives. Energy Environ. Sci., 2016, 9, P. 1552-1576.

[3] Yu Z., Leilaeioun M., Holman Z. Selecting tandem partners for silicon solar cells. Nat. Energy, 2016, 1, P. 16137.

[4] Leijtens T., Bush K.A., Prasanna R., McGehee M.D. Opportunities and challenges for tandem solar cells using metal halide perovskite semiconductors. Nat. Energy, 2018, 3, P. 828-838.

[5] Park N.G. Research direction toward scalable, stable, and high efficiency perovskite solar cells. Adv. Energy Mater., $2020,10(13)$, P. 1903106.

[6] Tejeda A., Choy W.C.H., Deleporte E., Graetzel M. Hybrid perovskites for photovoltaics and optoelectronics. J. Phys. D: Appl. Phys., 2020, 53(7), P. 070201.

[7] Ansari M.I.H., Qurashi A., Nazeeruddin M.K. Frontiers, opportunities, and challenges in perovskite solar cells: a critical review. J. Photochem. Photobiol. C: Photochem. Rev., 2018, 35, P. 1-24.

[8] Jiang Y., Almansouri I., Huang S., Young T., Li Y., Peng Y., Hou Q., Spiccia L., Bach U., Cheng Y., Greena M.A., Ho-Baillie A. Optical analysis of perovskite/silicon tandem solar cells. J. Mater. Chem. C, 2016, 4, P. 5679-5689. 
[9] Messmer C., Goraya B.S., Nold S., Schulze P.S., Sittinger V., Schön J., Goldschmidt J.C., Bivour M., Glunz S.W., Hermle M. The race for the best silicon bottom cell: efficiency and cost evaluation of perovskite-silicon tandem solar cells. Prog. Photovolt.: Res. Appl., 2020, https://doi.org/10.1002/pip.3372.

[10] Dewi H.A., Wang H., Li J., Thway M., Sridharan R., Stangl R., Lin F., Aberle A.G., Mathews N., Bruno A., Mhaisalkar S. Highly efficient semitransparent perovskite solar cells for four terminal perovskite-silicon tandems. ACS Appl. Mater. Interfaces, 2019, 11(37), P. 3417834187.

[11] Chen B., Zheng X., Bai Y., Padture N.P., Huang J. Progress in tandem solar cells based on hybrid organic-inorganic perovskite. Adv. Energy Mater, 2017, 7, P. 1602400.

[12] Jaysankar M., Filipic M., Zielinski B., Schmager R., Song W., Qiu W., Paetzold U.W., Aernouts T., Debucquoy M., Gehlhaar R., Poortmans J. Perovskite-silicon tandem solar modules with optimized light harvesting. Energ. Environ. Sci., 2018, 11, P. 1489-1498.

[13] Löper P., Moon S.-J., de Nicolas S.M., Niesen B., Ledinsky M., Nicolay S., Bailat J., Yum J.-H., De Wolf S., Ballif C. Organic-inorganic halide perovskite/crystalline silicon four-terminal tandem solar cells. Phys. Chem. Chem. Phys., 2015, 17, P. 1619-1629.

[14] Noh M.F.M., Teh C.H., Daik R., Lim E.L., Yap C.C., Ibrahim M.A., Ludin N.A., Yusoff A.R., Jange J., Teridi M.A.M. The architecture of the electron transport layer for a perovskite solar cell. J. Mater. Chem. C, 2018, 6, P. 682-712.

[15] Wang K., Olthof S., Subhani W.S., Jiang X., Cao Y., Duan L., Wang H., Du M., Liu S. Novel inorganic electron transport layers for planar perovskite solar cells: progress and prospective. Nano Energy, 2020, 68, P. 104289.

[16] Mahmood K., Sarwar S., Mehran M.T. Current status of electron transport layers in perovskite solar cells: materials and properties. RSC Adv., 2017, 7, P. 17044-17062.

[17] Larina L.L., Alexeeva O.V., Almjasheva O.V., Gusarov V.V., Kozlov S.S., Nikolskaia A.B., Vildanova M.F., Shevaleevskiy O.I. Very widebandgap nanostructured metal oxide materials for perovskite solar cells. Nanosystems: Physics, Chemistry, Mathematics, 2019, 10(1), P. 7075.

[18] Vildanova M.F., Nikolskaia A.B., Kozlov S.S., Shevaleevskiy O.I. Charge transfer mechanisms in multistructured photoelectrodes for perovskite solar cells. J. Phys.: Conf. Ser., 2020, 1697, P. 012187.

[19] Heo H., Han H.J., Lee M., Song M., Kim D.H., Im S.H. Stable semi-transparent $\mathrm{CH}_{3} \mathrm{NH}_{3} \mathrm{PbI}_{3}$ planar sandwich solar cells. Energ. Environ. Sci., 2015, 8(10), P. 2922.

[20] Chen B., Bai Y., Yu Z., Li T., Zheng X., Dong Q., Shen L., Boccard M., Gruverman A., Holman Z., Huang J. Efficient semitransparent perovskite solar cells for 23.0\% efficiency perovskite/silicon four terminal tandem cells. Adv. Energy Mat., 2016, 6(19), P. 1601128.

[21] Vildanova M.F., Nikolskaia A.B., Kozlov S.S., Karyagina O.K., Larina L.L., Shevaleevskiy O.I., Almjasheva O.V., Gusarov V.V. Nanostructured $\mathrm{ZrO}_{2}-\mathrm{Y}_{2} \mathrm{O}_{3}$-based system for perovskite solar cells. Doklady Physical Chemistry, 2019, 484(2), P. 36-38.

[22] Nikolskaia A., Vildanova M., Kozlov S., Tsvetkov N., Larina L., Shevaleevskiy O. Charge transfer in mixed phase TiO 2 photoelectrodes for perovskite solar cells. Sustainability, 2020, 12, P. 788.

[23] Ito S., Chen P., Comte P., Nazeeruddin M.K., Liska P., Péchy P., Grätzel M. Fabrication of screen-printing pastes from TiO 2 powders for dye?sensitized solar cells. Prog. Photovolt.: Res. Appl., 2007, 15, P. 603-612.

[24] Nikolskaia A.B., Kozlov S.S., Vildanova M.F., Shevaleevskiy O.I. Power conversion efficiencies of perovskite and dye-sensitized solar cells under various solar radiation intensities. Semiconductors, 2019, 53(4), P. 540-544.

[25] Ahn N., Son D.-Y., Jang I.-H., Kang S.M., Choi M., Park N.-G. Highly reproducible perovskite solar cells with average efficiency of $18.3 \%$ and best efficiency of $19.7 \%$ fabricated via lewis base adduct of lead (II) iodide. J. Am. Chem. Soc., 2015, 137(27), P. 8696-8699. 